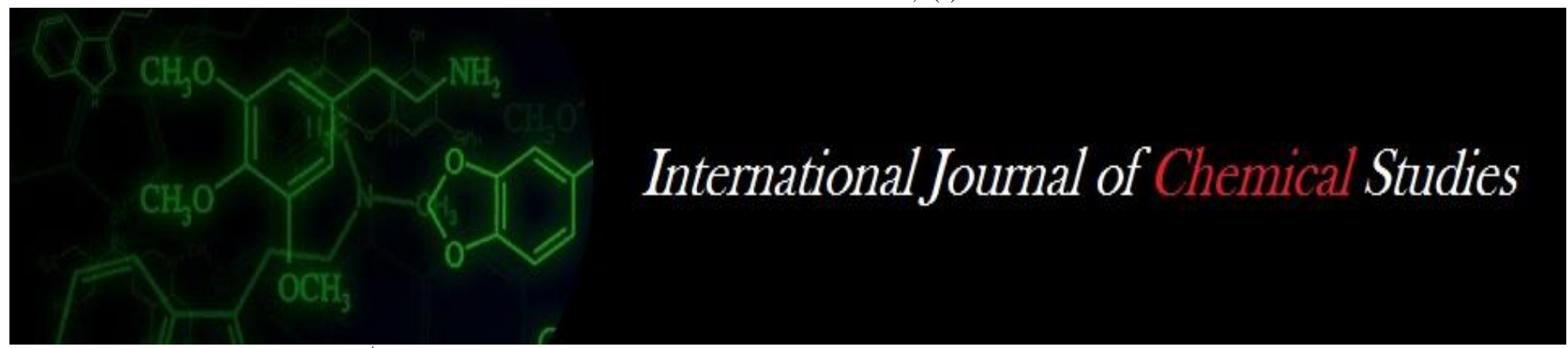

P-ISSN: 2349-8528

E-ISSN: 2321-4902

www.chemijournal.com

IJCS 2020; 8(1): 2646-2650

(C) 2020 IJCS

Received: 28-11-2019

Accepted: 30-12-2019

\section{CS Matholiya}

Ph.D. Scholar, Department of

Farm Machinery and Power

Engineering, CAET, AAU,

Godhra, Gujarat, India

\section{SK Jain}

Professor, Department of Farm

Structures, CAET, DBSKKV,

Dapoli, Maharashtra India

\section{AL Vadher}

Assistant Professor, Department of Farm Machinery and Power

Engineering, CAET, JAU,

Junagadh, Gujarat, India

MJ Nayaka

Project Assistance, National

Innovation Foundation,

Gandhinagar, Gujarat, India
Corresponding Author: CS Matholiya

Ph.D. Scholar, Department of Farm Machinery and Power

Engineering, CAET, AAU,

Godhra, Gujarat, India

\section{Determination of physical properties of guava (Psidium guajava)}

\section{CS Matholiya, SK Jain, AL Vadher and MJ Nayaka}

DOI: https://doi.org/10.22271/chemi.2020.v8.i1an.8672

\begin{abstract}
The physical properties of Lucknow-49 (Sardar Guava) variety of guava fruits and its peduncle, stem and plant parameters were studied for the development of harvesting device for guava fruit. The different properties of guava fruit, viz., its average equivalent diameter, sphericity, and average weight of single fruit, volume of ripe fruit, true density, specific gravity, average angle of external friction, coefficient of friction, angle of repose were found to be $63.77 \mathrm{~mm}, 0.9616,143.01 \mathrm{~g}, 144 \mathrm{~cm}^{3}, 0.976 \mathrm{~g} / \mathrm{cm}^{3}, 0.976,16.37^{\circ}$, 0.29 and $34.81^{\circ}$ respectively. The fruit's colour and shape were observed as dark green to yellowish green and round to ovate respectively. Apart from guava fruit, the physical properties of guava peduncle and stem were studied. An average diameter, length, angle with branch, cutting strength, stress and torque of guava peduncle were found to be $2.36 \mathrm{~mm}, 27.1 \mathrm{~mm}, 37^{\circ}, 137.401 \mathrm{~N}, 33.570 \mathrm{~N} / \mathrm{mm}^{2}$ and 0.325 $\mathrm{N}$ m respectively. An average diameter, length, cutting strength, stress and torque of guava stem were found to be $3.2 \mathrm{~mm}, 48.4 \mathrm{~mm}, 276.556 \mathrm{~N}, 41.322 \mathrm{~N} / \mathrm{mm}^{2}$ and $0.886 \mathrm{Nm}$ respectively. Guava plant parameters, viz., height of plant, plant canopy diameter and plant canopy volume were estimated as $3.825 \mathrm{~m}, 5 \mathrm{~m}$ and $24.76 \mathrm{~m}^{3}$ respectively. An automated approach was designed leveraging C\# programming language for self-serving calculations of different metrics during the course of this research study.
\end{abstract}

Keywords: Lucknow-49, harvesting device, C\# programming language

\section{Introduction}

India is the leading guava producer in the world today. Guava is the fourth most important fruit in terms of area and production after mango, banana and citrus. Guava is an important fruit crop of subtropical countries. In India, guava is cultivated on 261.4 thousand hectares of land, production is about 3648.2 thousand metric ton and productivity is about 13.9 metric ton per hectare. In Gujarat, guava is cultivated on 11.64 thousand hectares of land, and production is about 153.04 thousand metric ton. In Maharashtra, guava is cultivated on 12.49 thousand hectares of land, and production is about 140.86 thousand metric ton (HSD, 2017) ${ }^{[3]}$. In Gujarat and Maharashtra, commonly grown cultivars are Dharkar, Dholka, Lucknow-49 (Sardar Guava), Seedless nasik, Sindh. Development of guava harvesting device experiment has been conducted at ASPEE ARDF Tansa Farm, Mumbai.

The physical properties of Lucknow-49 variety of guava fruits and its peduncle, stem and plant parameters were studied for the development of harvesting device for guava fruit. This variety was developed at Ganesh Khend garden, Pune by the selection from Allahabad Safeda variety. Its plant are semi-dwarf, vigorous, spreading type, profuse bearing and heavy branching type with flat crown. Leaves are elliptic-ovate to oblong in shape. Its fruits are large, round to ovate in shape, dark green to yellowish green skin colour, white flesh and seeds are in plenty and harder than that of Allahabad Safeda (Singh, 2013a) ${ }^{[6]}$. Keeping quality of fruits is good. TSS and Vitamin ' $\mathrm{C}$ ' content also higher. The developed device was tested with Lucknow-49 cultivar.

Joseph and Priya (2011) ${ }^{[4]}$ reported that guava fruit is round to ovate or pear-shaped berry, white or yellow at maturity with yellow or dark pink flesh having numerous seeds. The fruits are usually ready to harvest after 4-5 month of flowering, when the fruit colour change from dark green to yellowish green. Harvesting should be done during the coolest part of the day, which is usually the early morning or late evening when physiological activities of the fruit are low. 
The fruit as well as its juice are freely consumed for their great taste and nutritional benefits. Singh (2013b) ${ }^{[7]}$ reported that the period of maturity depends on the climate condition of the growing areas. The maturity of fruits is determined based on colour change, specific gravity, total soluble solids, acidity, etc. At the time of harvest, the specific gravity of mature fruit becomes less than 1.0, i.e., mature fruits float in water. The fruits having specific gravity between 1.00 and 1.02 have better shelf life and are good for long distance transportation.

$\mathrm{C \#}$ is an objected oriented (class-based) developed around 2000 by Microsoft within its. NET initiative led by Anders Hejlsberg and later approved as an international standard by Ecma (ECMA-334) and ISO (ISO/IEC 23270:2018) (Anonymous, 2017). C\# is one of the programming languages designed for the Common Language Infrastructure (CLI) and it is the advance technology based on $\mathrm{C}$ and $\mathrm{C}++$ programming languages. $\mathrm{C} \#$ programming language was leveraged for calculations of guava cultivars parameters during the course of this research study.

\section{Materials and Methods}

For the development of harvesting device, estimation of physical condition or geometry of guava fruit and plant are necessary to be measured. The methodology was used for measurement and determination of physical properties of guava fruits and plant parameters.

\section{Physical properties of guava fruit}

Physical properties of fruit is being the base for designing any device to work with that fruit, Physical properties were determined for the Lucknow 49 (Sardar guava) variety of ripe guava fruits.

\section{Size}

The size of an irregular shaped fruit can be determined by equivalent diameter $\left(D_{e}\right)$. The dimensions like length (l), breadth (b) and thickness (t) were measured on three major axis of the fruit. Randomly selected fifty fruits were procured from the field to the laboratory and their dimensions were measured using digital vernier calliper (Mohsenin, 1980) ${ }^{[5]}$. Size of each fruit in terms of equivalent diameter $\left(D_{e}\right)$ was determined by using following formula.

$D_{e}=(l \times b \times t)^{I / 3}$

Where,

$1=$ Length $(\mathrm{mm})$,

$\mathrm{b}=$ Breadth $(\mathrm{mm})$ and

$\mathrm{t}=$ Thickness $(\mathrm{mm})$.

\section{Sphericity}

The sphericity of guava fruits $(\varnothing)$ was calculated using the following relationship (Mohsenin, 1980) ${ }^{[5]}$. $\varnothing=\frac{(1 \times b \times t)^{1 / 3}}{1}$

\section{Fruit shape and colour}

The shape of the actual fruit was visually observed and compared with the shape in the charted standard shapes. Visual observations were made for evaluation of colour and compared with the standard colour charts. Based on visual observation the shape and colour were judged (Mohsenin, 1980) ${ }^{[5]}$

\section{Volume, true density and specific gravity}

Platform scale method was used to determine the volume, true density and specific gravity of each type of fruits. Volume of guava fruit was measured by any number of fruits can be taken which can be accommodated in the beaker as shown in Fig. 1 (A). (Mohsenin, 1980) ${ }^{[5]}$.

Volume $\left(\mathrm{cm}^{3}\right)=\frac{\text { Weight of displaced fluid }(\mathrm{g})}{\text { Density of fluid }\left(\mathrm{g} / \mathrm{cm}^{3}\right)}$

True density $\left(\mathrm{g} / \mathrm{cm}^{3}\right)=\frac{\text { Weight of sample in air }(\mathrm{g})}{\text { Volume of displace fruit }\left(\mathrm{cm}^{3}\right)}$

Specific gravity $=\frac{\text { Weight of sample in air }(\mathrm{g}) \times \text { Specific gravity of fluid }}{\text { Weight of displace fruit }(\mathrm{g})}$

\section{Angle of external friction}

The inclined plane apparatus (Fig. 1 (B)) method as described by Dutta et al. (1988) ${ }^{[2]}$ was used for determination of coefficient of friction.

$\mu=\tan \varnothing=(y / x)$

$\varnothing=\tan ^{-1}(\mathrm{y} / \mathrm{x})$

Where,

$\mu=$ Coefficient of friction

$\varnothing=$ Angle of external friction

$\mathrm{x}=$ Horizontal distance

$\mathrm{y}=$ Vertical distance.

\section{Angle of repose}

The angle of repose of guava fruit (Fig. 1(C) was determined as the method explained by Waziri and Mittal (1983) ${ }^{[9]}$.

$\theta=\tan ^{-1}\left(\frac{\mathrm{h}}{\mathrm{r}}\right)$

Where,

$\theta=$ Angle of repose (degree),

$\mathrm{h}=$ Height of pile $(\mathrm{cm})$ and

$\mathrm{r}=$ Radius of pile $(\mathrm{cm})$. 


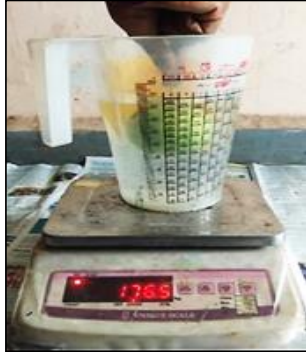

(A)

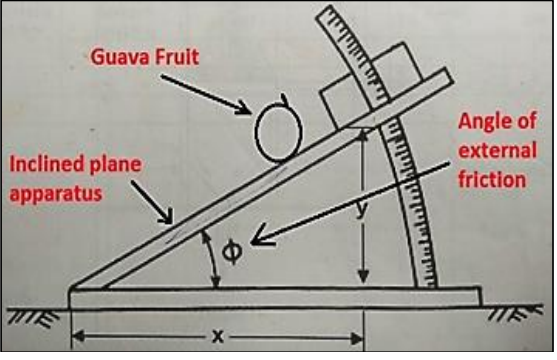

(B)

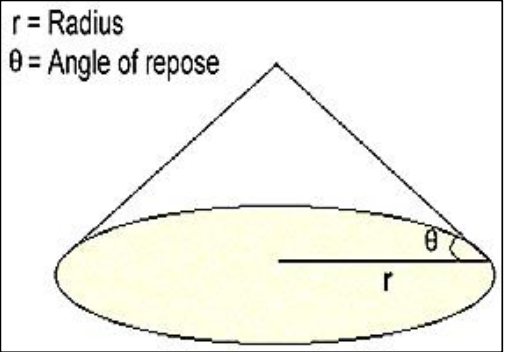

(C)

Fig 1: (A) Measurement of fruit volume (B) Coefficient of friction and Angle of external friction (C)Angle of repose Physical properties of guava peduncle and stem

Physical properties of guava peduncle and stem are used for design of cutting mechanism of harvesting device. Guava fruits are required to cut with peduncle as well as stem. Guava fruit with 1-2 leaves is considered as a guava peduncle and without leaf it is considered as a guava stem. Generally, guava fruit with leaf is preferable for better shelf life of fruits and its high nutritional value. It is desirable to harvest the fruits with the stem along with one or two leaves (Singh, 2013c) ${ }^{[8]}$. Diameter and length of guava peduncle were measured using a Vernier caliper having least count of $0.1 \mathrm{~mm}$. Angle of guava peduncle or stem with branch was measured using a protractor and divider. This angle shows the angle at which guava fruit hangs in relation to adjoining branch and also gives the idea of putting the device at fruit peduncle or stem and to cut the fruit along with leaf.

\section{Cutting strength of guava peduncle and stem}

Cutting strength of guava peduncle and stem are being used for design of circular serrated cutting blade of harvesting device. Warner-Bratzler Blade with Rectangular Hole probe (Fig. 2(A)) was used to measure cutting strength of guava peduncle and stem.

\section{Stress of guava peduncle and stem}

Stress of guava peduncle or stem was determined using the ratio of the cutting strength to the area required for cutting of guava peduncle or stem as shown in the equation below.

$\sigma=\frac{F}{A}$

Where,

$\sigma=$ Stress $\left(\mathrm{N} / \mathrm{mm}^{2}\right)$

$\mathrm{F}=$ Cutting strength or applied force $(\mathrm{N})$

$\mathrm{A}=$ Cross-sectional area required for cutting of guava peduncle or stem $\left(\mathrm{mm}^{2}\right)$

\section{Torque required to cut guava peduncle or stem}

Torque applied by the blade which is being used to cut the peduncle or stem of fruit at optimum force among this diameter of peduncle or stem.

\footnotetext{
Torque requied to cut guava Force applied $(\mathrm{N}) \times$ Diameter of guava peduncle or stem $(\mathrm{N} \mathrm{m})=$ peduncle or stem $(\mathrm{m}) \ldots(10)$
}

\section{Guava plant parameters}

Parameter of guava plant was used to make a design of any device to work with that fruit. Plant parameters were estimated, viz., plant height, plant canopy diameter and plant canopy volume (Fig. 2(B)).

\section{Plant canopy volume}

$\mathrm{PSCV}=\frac{\pi D_{1}^{2}}{4}+\frac{2\left(H_{T}-H_{C}\right)}{3}+\left(H_{C}-H_{S}\right)$

Where,

$\mathrm{PS}_{\mathrm{CV}}=$ Plant canopy volume $\left(\mathrm{m}^{3}\right)$,

$\mathrm{H}_{\mathrm{T}}=$ Overall canopy height above ground level $(\mathrm{m})$,

$\mathrm{H}_{\mathrm{C}}=$ Height to the point of maximum canopy diameter $(\mathrm{m})$,

$\mathrm{H}_{\mathrm{S}}=$ Height from ground to canopy skirt (m),

$\mathrm{D}_{1}=$ Canopy diameter parallel to the row (N-S direction) (m).

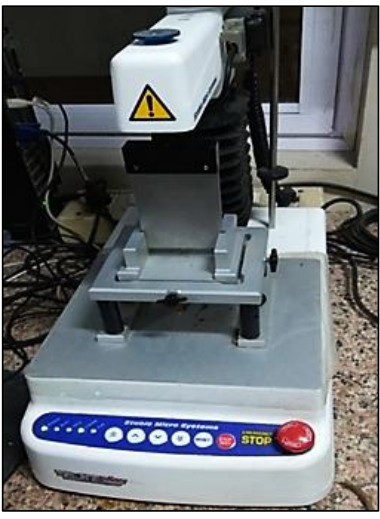

(A) Probe: Warner-bratzler blade with rectangular hole

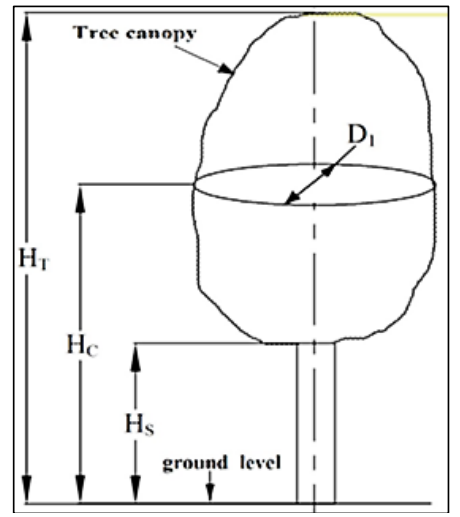

(B) Measurement of plant canopy volume

Fig 2

\section{Results and Discussion}

Minimum, maximum and average value of the physical properties of guava fruit, physical properties of guava peduncle and stem and guava plant parameters are mentioned below in tabulated form: 
Table 1: Physical properties of guava fruits

\begin{tabular}{|c|c|c|c|c|}
\hline Sr. No. & Name of physical property & Min & Max & Avg. \\
\hline \multirow{3}{*}{1} & Length, $(\mathrm{mm})$ & 55 & 90 & 66.39 \\
\cline { 2 - 5 } & Bize & 54 & 74 & 63.81 \\
\cline { 2 - 5 } & Thickness, $(\mathrm{mm})$ & 47 & 73 & 61.29 \\
\hline & Equivalent diameter, $(\mathrm{mm})$ & 52.35 & 78.09 & 63.77 \\
\hline 2 & Sphericity & 0.8677 & 0.9975 & 0.9616 \\
\hline 3 & Weight, $(\mathrm{g})$ & 81 & 227 & 143.01 \\
\hline 4 & Volume of ripe fruit, $\left(\mathrm{cm}^{3}\right)$ & 85 & 220 & 144 \\
\hline 5 & True density $\left(\mathrm{g} / \mathrm{cm}^{3}\right)$ & 0.904 & 1.035 & 0.976 \\
\hline 6 & Specific gravity & 0.904 & 1.035 & 0.976 \\
\hline 7 & Angle of external friction, $($ degree $)$ & 14.57 & 18.26 & 16.37 \\
\hline 8 & Coefficient of friction & 0.26 & 0.33 & 0.29 \\
\hline 9 & Angle of repose, $($ degree $)$ & 33 & 35.74 & 34.81 \\
\hline 10 & Colour & \multicolumn{3}{|c}{ Rark green to yellowish green } \\
\hline 11 & Shape & \multicolumn{3}{c}{} \\
\hline
\end{tabular}

The different properties of guava fruit, viz., an average equivalent diameter, sphericity, average weight of single fruit, volume of ripe fruit, true density, specific gravity, average angle of external friction, coefficient of friction, angle of repose were found to be $63.77 \mathrm{~mm}, 0.9616,143.01 \mathrm{~g}, 144 \mathrm{~cm}^{3}$,
$0.976 \mathrm{~g} / \mathrm{cm}^{3}, 0.976,16.37^{\circ}, 0.29$ and $34.81^{\circ}$ respectively. The colour and shape of guava fruit were observed like dark green to yellowish green and round to ovate. Colour and shape of the fruit were visually observed and compared with standard colour chart and charted standard shapes.

Table 2: Physical properties of guava peduncle and guava stem

\begin{tabular}{|c|c|c|c|c|c|}
\hline Sr. No. & Nan & of physical property & Min & Max & Avg. \\
\hline \multirow{6}{*}{1} & \multirow{6}{*}{$\begin{array}{c}\text { Guava } \\
\text { Peduncle }\end{array}$} & Diameter, (mm) & 2 & 3 & 2.36 \\
\hline & & Length, (mm) & 17 & 35 & 27.1 \\
\hline & & Angle with branch, (degree) & 25 & 47 & 37 \\
\hline & & Cutting strength, (N) & 100.754 & 176.174 & 137.401 \\
\hline & & Stress $\left(\mathrm{N} / \mathrm{mm}^{2}\right)$ & 21.912 & 56.106 & 33.570 \\
\hline & & Torque required $(\mathrm{N} \mathrm{m})$ & 0.222 & 0.465 & 0.325 \\
\hline \multirow{5}{*}{2} & \multirow{5}{*}{ Guava Stem } & Diameter, $(\mathrm{mm})$ & 2 & 4 & 3.2 \\
\hline & & Length, (mm) & 30 & 60 & 48.4 \\
\hline & & Cutting strength, $(\mathrm{N})$ & 241.305 & 328.240 & 276.556 \\
\hline & & Stress $\left(\mathrm{N} / \mathrm{mm}^{2}\right)$ & 20.570 & 85.894 & 41.322 \\
\hline & & Torque required $(\mathrm{N} \mathrm{m})$ & 0.539 & 1.084 & 0.886 \\
\hline
\end{tabular}

Apart from guava fruit, the physical properties of guava peduncle and stem were also studied with an average diameter, length, angle with branch, cutting strength, stress and torque of guava peduncle of $2.36 \mathrm{~mm}, 27.1 \mathrm{~mm}, 37^{\circ}$,
137.401 $\mathrm{N}, 33.570 \mathrm{~N} / \mathrm{mm}^{2}$ and $0.325 \mathrm{~N}$ m respectively. An average diameter, length, cutting strength, stress and torque of guava stem were measured and found to be $3.2 \mathrm{~mm}, 48.4 \mathrm{~mm}$, $276.556 \mathrm{~N}, 41.322 \mathrm{~N} / \mathrm{mm}^{2}$ and $0.886 \mathrm{~N}$ m respectively.

Table 3: Guava plant parameters

\begin{tabular}{|c|c|c|c|c|c|}
\hline Sr. No. & & Name of guava plant parameter & Min & Max & Avg. \\
\hline 1 & & Height of plant, (m) & 3.65 & 4 & 3.825 \\
\hline 2 & & lant canopy diameter (N-S direction), (m) & 4.1 & 5.4 & 4.94 \\
\hline 3 & & lant canopy diameter (E-W direction), (m) & 4.3 & 5.3 & 4.93 \\
\hline 4 & & Plant canopy volume $\left(\mathrm{m}^{3}\right)$ & 17.47 & 31.46 & 24.78 \\
\hline \multirow{4}{*}{5} & \multirow{4}{*}{$\begin{array}{c}\text { Different } \\
\text { canopy parameters }\end{array}$} & Overall canopy height above ground level $\left(\mathrm{H}_{\mathrm{T}}\right)(\mathrm{m})$ & 3.65 & 4 & 3.825 \\
\hline & & Height to the point of maximum canopy diameter $\left(\mathrm{H}_{\mathrm{C}}\right)(\mathrm{m})$ & 1.65 & 2.21 & 1.97 \\
\hline & & Height from ground to canopy skirt $\left(\mathrm{H}_{\mathrm{s}}\right)(\mathrm{m})$ & 0.45 & 1.1 & 0.828 \\
\hline & & Canopy diameter parallel to the row $\left((\mathrm{N}-\mathrm{S}\right.$ direction $)\left(\mathrm{D}_{1}\right)(\mathrm{m})$ & 4.1 & 5.4 & 4.94 \\
\hline
\end{tabular}

Plant parameters, viz., height of plant, plant canopy diameter and plant canopy volume were estimated and found to be $3.825 \mathrm{~m}, 5 \mathrm{~m}$ and $24.76 \mathrm{~m}^{3}$ respectively.

\section{Calculation using C\# programming language}

The calculation of different parameters was automated through C\# Programming language. Single data calculated screenshots of output window of $\mathrm{C} \#$ programming language are shown in Fig. 3 below. 


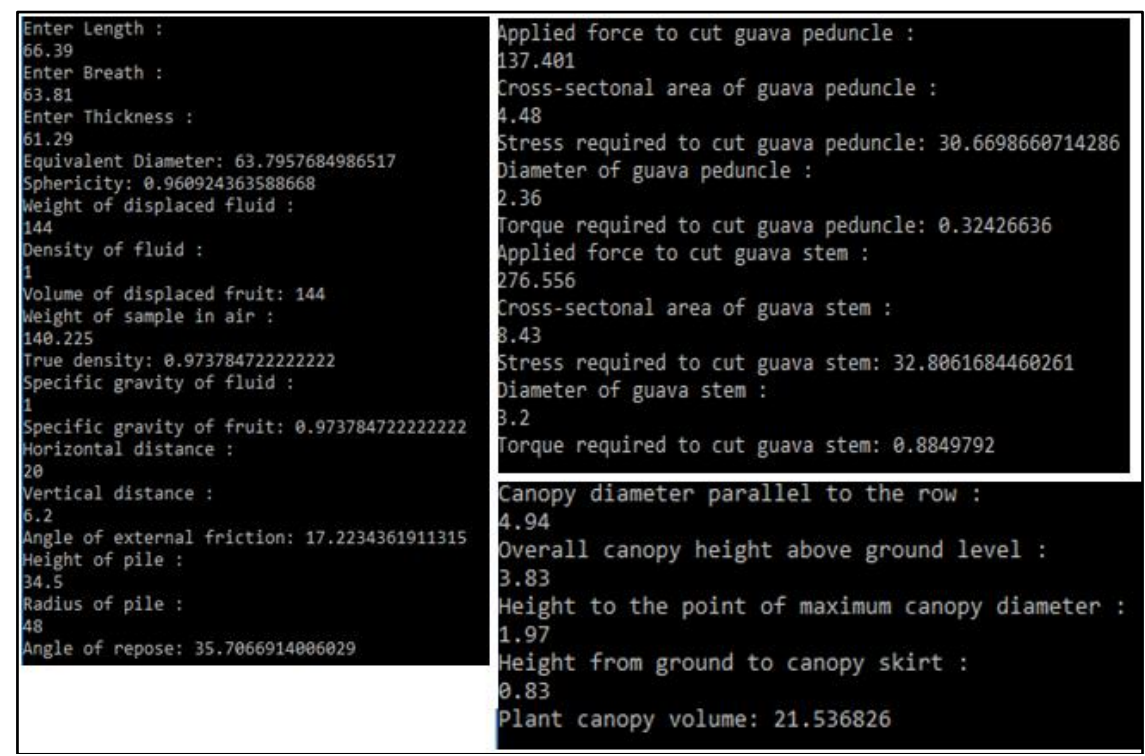

Fig 3: Screenshots of output window of C\# Programming language

\section{Conclusions}

The physical properties of guava fruit, physical properties of peduncle and stem and plant parameters were measured and calculated using C\# programming language. The data will be used for the design and development of guava harvesting device.

\section{Acknowledgements}

I am sincerely thankful to Shri Sharad L, Patel, Director, ASPEE Agricultural Research and Development Foundation and including other team members for providing financial assistance (Junior Research Fellowship) and opportunity to engage this study and to provide necessary information and support as well.

\section{References}

1. Anonymous. C\# Language Specification. ECMA International, Retrieved, 2017, 2019, https://www.ecmainternational.org/publications/files/ECMA-ST/ECMA334.pdf.

2. Dutta SK, Nema VK, Bhardwaj RK. Physical properties of grains. Journal of Agricultural Engineering Research. 1988; 39:259-268.

3. HSD, Horticultural statistics at a glance. Horticultural Statistics Division, Department of agril. Co-operation and farmer's welfare, Ministry of agriculture and farmer's welfare, GOI, 2017, 155-156. http://nhb.gov.in/statistics/ Publication/ Horticulture $\% 20$ At $\%$ 20a\%20Glance $\% 202017 \% 20$ for\%20net\%20uplod\%20(2). Pdf, Accessed on 10 May 2018.

4. Joseph B, Priya MR. Review on Nutritional, Medicinal and Pharmacological Properties of Guava (Psidium guajava Linn.). Int J Pharma Bio Sci. 2011; 1(1):53-59.

5. Mohsenin NN. Physical properties of plant and animal materials. Gordon and Breach Science Publishers, New York, 1980, 51-58.

6. Singh G. Guava, Book Published by Mrinal Goel, Westville Publishing House, New Delhi, 2013a, 21.

7. Singh G. Guava, Book Published by Mrinal Goel, Westville Publishing House, New Delhi, 2013b,105.

8. Singh G. Guava, Book Published by Mrinal Goel, Westville Publishing House, New Delhi, 2013c, 106.

9. Waziri AN, Mittal JP. Design related physical properties of selected agricultural products. AMA. 1983; 14:59-62. 